\section{B A Institute of \\ YK Business Administration \\ 六下 \\ Karachi \\ Leadership and Ideas for Tomorrow}

Business Review

Volume 7 Issue 2 July-December 2012

7-1-2012

\title{
Role of education in human development: A study of South Asian countries
}

Amna Mahmood

International Islamic University, Islamabad, Pakistan

Follow this and additional works at: https://ir.iba.edu.pk/businessreview

Part of the Educational Leadership Commons, and the Higher Education Commons

(c) (†)

This work is licensed under a Creative Commons Attribution 4.0 International License.

\section{Recommended Citation}

Mahmood, A. (2012). Role of education in human development: A study of South Asian countries. Business Review, 7(2), 130-142. Retrieved from https://doi.org/10.54784/1990-6587.1210

This article is brought to you by iRepository for open access under the Creative Commons Attribution 4.0 License and is available at https://ir.iba.edu.pk/businessreview/vol7/iss2/11. For more information, please contact irepository@iba.edu.pk. 


\title{
CASE STUDY
}

\section{Role of Education in Human Development: A Study of South Asian Countries}

\author{
Amna Mahmood \\ International Islamic University, Islamabad, Pakistan.
}

\begin{abstract}
Although education is a source of better income and jobs, it has much value for social development as an imperative for the development of human capital. That is why it is considered to be a vital part of development economics. Most of the economists have a consensus that the pace of economic and social development of a country depends on its human resource rather than its material resources. But South Asian policy makers paid merely a lip service to this area. In this region the demographic nightmare poses a key challenge for human development since the population has more than doubled during the last three decades. This population could have become the real wealth of these nations, if sufficient investment had been made in developing human capital. Human resource development is the most deprived area in South Asia and this region spends less than five per cent of its combined GNP on education and health which is one of the lowest even in the developing countries. That is why; rapidly growing population has become a major liability and a source of human deprivation.

In global context, South Asia has been the least developed region of the world, both in terms of its income and human developments index. The percentage of adult literacy is the lowest among developing nations, even behind Sub-Sahara Africa. In fact South Asia has emerged as the most illiterate region in the world. Its human capital is being wasted for a long time. The article defines the term 'human capital and discusses the role, which education and training play in the process of developing human capital. Social capital signifies sound institutions and good governance, which again depend on coverage and quality of education. It also discusses as to how education contributes to the development of human resource which supports not only economic development but also help to develop sound institutions and good governance. It also explores with the help of different studies at how education helps to address gender issue, health care and population control creating a strong nation ready to face the challenges of the twenty-first century.
\end{abstract}

Key words: Human development, South Asia, Education human Capital, Literacy rate.

\section{Introduction}

Kofi Annan, Secretary General of the UN, writes: 
Education is a human right with immense power to transform. On its foundation rests the corner stone of freedom, democracy and sustainable human development (UNICEF Report 1999, 4).

Education is the key to building human capital and human capital is vital for building a nation. The East Asian miracles are primarily due to their emphasis on basic and technical education. Statistics show that there is no industrial society today with an adult literacy rate of less than 80 per cent. Education is not only a way to better income and employment opportunities for all or a source of economic growth for the nation. But it also plays a pivotal role in improving other social indicators. It leads to better life expectancy and health care, smaller family norms, greater community and political participation. It also leads to reduction of inequality, poverty elevation and good governance. It is a pre-condition to establish democracy in a country.

South Asia became the most malnourished and illiterate region in the world facing acute poverty. With its rich still unexploited resources, it has all the potential to be emerged as most vibrant region provided it adopts a new development strategy focused on developing human capital. Political commitment and society's full participation can help to meet the formidable education challenges of South Asia.

Most economists agree that the pace and character of economic and social development in a country is determined by its human resources and not by its physical resources. Professor Frederick Harbison says that the "Human resources constitute the ultimate basis of wealth of nations. Capital and natural resources are passive factors of production while human beings are the active agents who accumulate capital, exploit natural resources, build social, economic and political organizations and carry forward national development. Nonetheless a country which is unable to develop the skills and knowledge of its people and to utilise them effectively in the national economy would be unable to develop anything else.” (Harbison 1973, 18)

The importance of education for development was fully acknowledged by classical economists like Adam Smith (1776), Alfred Marshall (1890), Frederick Engels (1845), Karl Marx, etc. The recent political economists like Schultz (1988), Becker (1993) and Sen (1995) reaffirmed it. But in South Asia, policy makers ignored this aspect and they allocated insufficient resources for education; a bulk of them was allocated to wrong educational priorities. Public spending on education is still low in South Asia, even though it has increased substantially over the last few decades. Table 1 shows the comparison with other religions.

Table 1: Public spending on Education: South Asia in comparison with other religions.

\begin{tabular}{|l|c|c|}
\hline Region & As\% of GNP1993-94 & $\begin{array}{l}\text { As\% of total government } \\
\text { expenditures (1992-94) }\end{array}$ \\
\hline South Asia & 3.5 & 10.9 \\
\hline East Asia (excel. China) & 4.5 & 17.3 \\
\hline $\begin{array}{l}\text { All Developing Countries } \\
\text { (excel. South Asia) }\end{array}$ & 3.6 & 15.7 \\
\hline Arab States & 5.5 & 20.5 \\
\hline Sub-Saharan Africa & 5.5 & 19.9 \\
\hline
\end{tabular}

Source: (Haq 1998, 132) 
The low rate of public spending in South Asia is due to low level of political commitment on one hand and due to the heavy military spending (Haq 1999, 5), debt servicing and sick public enterprises on the other. In fact militarisation is the major cause of poverty and least social development. Both India and Pakistan spend \$1.70 and \$4.32 on military and debt servicing respectively, against every single dollar to be on social development. The tensions have become more volatile since the nuclear tests in May 1998 by India and Pakistan (Spot Light).

Demographic nightmare poses one of the key challenges to human development in the region. The population has become more than double during the last three decades. This population could have become the real wealth of these nations if sufficient investments had been made in human development. But since South Asian countries spend very little on education and health of its people i.e. less than five per cent of its combined GNP, their rapidly growing populations have become a major liability and a source of human deprivation (Haq 1997, 16, 66).

\section{Global Context}

In the global context, the South Asian region has been the least developed region of the world, both in terms of human development and income. These facts are illustrated in Table 2. Considerable decline in the relative performance of South Asia has occurred in the last three decades. From Table 2 it is clear that there are only two areas in which South Asia has made progress, one in increasing its share in world population, from 19 per cent to 22 per cent in 1993 and second in the world's illiterate adult population. The literacy rate of South Asia has slipped behind that of Sub-Saharan Africa.

Table 2: South Asia in the Global Framework

\begin{tabular}{|c|c|c|c|c|c|c|c|c|}
\hline & \multicolumn{2}{|c|}{$\begin{array}{l}\text { Population } \\
\text { million }\end{array}$} & \multicolumn{2}{|c|}{$\begin{array}{c}\text { Real GDP } \\
{ }^{\circ} \text { PPP dollars } \\
\text { (billion) }\end{array}$} & \multicolumn{2}{|c|}{$\begin{array}{c}\text { Absolute } \\
\text { Poverty } \\
\text { (million) }\end{array}$} & \multicolumn{2}{|c|}{$\begin{array}{l}\text { Illiterate Adults } \\
\text { (million) }\end{array}$} \\
\hline & 1960 & 1993 & 1960 & 1993 & 1960 & 1993 & 1960 & 1993 \\
\hline World & 2,996 & 5,508 & 5,303 & 30,542 & $\mathrm{n} / \mathrm{a}$ & 1,314 & 735 & 853 \\
\hline $\begin{array}{l}\text { South } \\
\text { Asia }\end{array}$ & 564 & 1,191 & 365 & 1,632 & $\mathrm{n} / \mathrm{a}$ & 527 & 234 & 396 \\
\hline $\begin{array}{l}\text { Share of } \\
\text { South } \\
\text { Asia in } \\
\text { the } \\
\text { World(\%) }\end{array}$ & 19 & 22 & 6.9 & 5.3 & $\mathrm{n} / \mathrm{a}$ & 40 & 32 & 46 \\
\hline
\end{tabular}

*SPPP: The power of a country's currency to purchase goods and services equivalent to worth one \$US. (Source: Haq 1997, 8)

Despite the GDP growth rates of 5 to 6 per cent a year as compared to the negative growth rate in sub-Saharan countries, the literacy rate in South Asia increased by 1.8 per cent a year during 1960-93 compared to 3.1 in Sub- Saharan Africa. The percentage of adult literacy in South Asia is the lowest among the developing nations. Table 3 shows the facts about the literacy rate in various regions of the world. 
Table 3: Adult literacy in various Regions. (\%)

\begin{tabular}{|l|c|}
\hline Regions & Adult Literacy Rate (\%) \\
\hline South Asia & $48 \%$ \\
\hline Arab States & $53 \%$ \\
\hline Sub- Saharan Africa & $55 \%$ \\
\hline Developing Countries & $69 \%$ \\
\hline Latin America \&Caribbean & $86 \%$ \\
\hline East Asia (excel .China) & $86 \%$ \\
\hline
\end{tabular}

Source: (Haq 1997: 15).

Statistics mentioned in the Table 3 show clearly that South Asia is having the lowest literacy rate in the world. Its human capital is being wasted for a longtime.

\section{Human Capital}

Human capital is considered to be an engine of growth because it is the only instrument to utilise all the material resources. Human capital is defined as the group of useful, valuable and concerned knowledgeable people who are the product of relevant education and training process. For development of this capital, human stock needs investment in the form of formal education from primary to secondary level. It increases the capacity of a labourer to work and in turn his productivity which is rewarded by high wages in the labour market. It is considered to be the most valid 'economic explanation' for higher rewards for the educated workers in the job markets (Becker 1993 \& Schultz 1998). Empirical evidences shows that in Bangladesh, the average salary paid to a secondary school qualified woman is as much as seven times higher than that given to an illiterate woman (World Bank 1993b). Similarly skilled labour in construction industry receives double wages of unskilled workers. A study by Jamison and Lau (1982) conclude that the output of farmers increases by about 8 per cent with four years of schooling.

Pakistan is no exception to this trend. Here the greater increase in agriculture productivity (2.7 per cent) was associated with a ten per cent increase in male literacy, compared with less than half this productivity increase for a ten per cent growth in some other agriculture inputs (Rose Grant and Evenson 1993). It is amazing that not only the productivity of educated workers is increased but also that of their neighbouring labour is raised by having a role model (Foster 1995). At the same time, schooling is a powerful weapon to fight against child labour (UNICEF 1997). It is also helpful in poverty alleviation especially when the other market options are there augmented by new technologies (Rosenzweig 1995).

The two World Bank studies (1993b \& 1995a) present most powerful arguments in favour of this school of thought that believe in inevitable place of human capital for development. On the basis of experiences of 192 countries of the World, these studies concluded that "as much as two-third of the wealth of nations consists of human and social capital.” Social Capital signifies, sound institutions and good governance, which in turn depends largely on the coverage and quality of education (Haq and Haq 1998, 25). In countries like Japan that lacks a good natural resource base, human and social capital are estimated to have contributed 85 per cent to the total national wealth, while physical capital (machinery and physical infrastructure) 14 per cent and natural capital only one per 
cent. The relationship of social and human capital in national development is mentioned in the Table 4.

Table 4: Percentage share of Contributions to the Human Capital.

\begin{tabular}{|l|c|c|c|}
\hline Regions & Natural Capital & Physical Capital & Human Capital \\
\hline Sub-Saharan Africa & 52 & 17 & 31 \\
\hline East Asia \& Pacific & 12 & 13 & 75 \\
\hline South Asia & 9 & 15 & 76 \\
\hline Latin America \&Caribbean & 35 & 15 & 50 \\
\hline Middle East \&North Africa & 32 & 29 & 39 \\
\hline Eastern Europe & 43 & 16 & 41 \\
\hline High Income Countries & 17 & 16 & 67 \\
\hline Other Developing Countries & 28 & 16 & 64 \\
\hline
\end{tabular}

Source: World Bank 1995 c.

These figures prove that if a country lack human capital it cannot progress because natural resources cannot overcome the deficiency of natural capital while scarcity of natural resources can be dealt with by constructing human capital. The visible example is that of OPEC countries which have large reserves of resources but since they have not been concentrating on human development they are still on the status of developing countries, even having attractive per capita income.

\section{Importance of Education}

The human capital is inevitable for building any nation and for that purpose education is the only key. No doubt, it is not possible without the relevant education according to the needs of society and demands of the global job markets. Secondly, it must be provided to every citizen of state without discrimination of gender, economic and regional basis. Although the equal distribution of education facilities does not always overcome the income disparities among different groups but it at least help to reduce them. Furthermore it adds up to enhance the living standards and life style of a nation (Tilak 2002, 9). East Asian experience shows the importance of basic and technical education in building a stock of valuable and required human capital. Statistics show that no society can acquire the status of industrialized one without education more than 80 per cent (Haq 1998, 26).

\section{East Asian Example}

The human capital of South Asia is deficient both in terms of quantity and quality. This becomes painfully clear when South Asian situation is compared with the experience of East Asia (excel. China) over the last three decades. In 1960 South Asia enjoyed a real per capital income very closed to that of East Asia. But now South Asian average per capital income is only one tenth of that in East Asia. The Table 5 shows the comparison. 
Table 5 : South Asia Compared with East Asia (excel. China)

\begin{tabular}{|c|c|c|c|c|c|c|}
\hline & \multicolumn{2}{|c|}{1960} & \multicolumn{2}{|c|}{1993} & \multicolumn{2}{|c|}{$\begin{array}{l}\text { Annual Rate of } \\
\text { change(1993) }\end{array}$} \\
\hline & $\begin{array}{l}\text { South } \\
\text { Asia }\end{array}$ & $\begin{array}{l}\text { East } \\
\text { Asia }\end{array}$ & $\begin{array}{l}\text { South } \\
\text { Asia }\end{array}$ & $\begin{array}{l}\text { East } \\
\text { Asia }\end{array}$ & $\begin{array}{l}\text { South } \\
\text { Asia }\end{array}$ & $\begin{array}{l}\text { East } \\
\text { Asia }\end{array}$ \\
\hline GDP per Capital (PPP\$) & 658 & 869 & 1,730 & 11,088 & 2.2 & 8.0 \\
\hline Life Expectancy Years & 44 & 55 & 61 & 71 & 1.0 & 0.8 \\
\hline Adult literacy rate & $\begin{array}{c}32 \\
(1970)\end{array}$ & $\begin{array}{c}88 \\
(1970)\end{array}$ & 48 & 98 & 1.4 & 0.5 \\
\hline Public spending on & 0.5 & 0.2 & 1.4 & 2.3 & 3.5 & 8.5 \\
\hline \multicolumn{7}{|l|}{ Health (as\% of GDP) } \\
\hline $\begin{array}{l}\text { Public spending on } \\
\text { education(as \% of GNP) }\end{array}$ & 2.0 & $\begin{array}{c}3.7 \\
(1980)\end{array}$ & $\begin{array}{c}3.4 \\
(1992)\end{array}$ & $\begin{array}{c}4.3 \\
(1992)\end{array}$ & 1.7 & 1.3 \\
\hline Military Spending & 113 & 273 & $\begin{array}{c}72 \\
(1991)\end{array}$ & $\begin{array}{c}49 \\
(1991)\end{array}$ & -1.5 & -5.6 \\
\hline Population growth rate & $\begin{array}{c}2.4 \\
(1965- \\
80)\end{array}$ & $\begin{array}{c}1.9 \\
(1965- \\
80)\end{array}$ & $\begin{array}{c}2.1 \\
(1980- \\
93)\end{array}$ & $\begin{array}{c}1.5 \\
(1980- \\
93)\end{array}$ & & \\
\hline $\begin{array}{l}\text { GNP per capital growth } \\
\text { rate }\end{array}$ & $\begin{array}{c}1.4 \\
(1965- \\
80)\end{array}$ & $\begin{array}{c}5.1 \\
(1965- \\
80)\end{array}$ & $\begin{array}{c}2.9 \\
(1980- \\
93)\end{array}$ & $\begin{array}{c}7.5 \\
(1980- \\
93)\end{array}$ & & \\
\hline
\end{tabular}

Source: (Haq 1997, 14).

The major differences in their development strategies centred around five main areas: the focus on basic education, the promotion of exports; land and credit reforms; saving and investment policies; and the extent of co-operation between the public and private sector. In the period of three decades only, East Asia has become a different world altogether while South Asia has fallen much behind. In fact the East Asian economic miracles are based on the educational miracles. The per capita income in East Asia was close to that of South Asia in 1960, but the education levels preceding the rapid economic growth of the last three decades were often higher than the present education levels in South Asia. For instance in 1960, only 30 per cent of Pakistani were enrolled in primary schools, compared to 94 per cent in South Korea. The East Asian literacy rate was already 88 per cent compared to the low literacy rate of 32 per cent in South Asia. South Asia governments failed to realise that broad based-education is essential for sustained, equitable economic growth. That's why, per capita annual investment in education and health sectors, is \$5 in Bangladesh, \$10 in Pakistan and \$14 in India, compared to \$150 in Malaysia and \$160 in Republic of Korea. Though several East Asian economies are passing through a short-term liquidity crisis at present but many analysts are predicting that East Asia would come out of its current financial crisis even stronger, because of its abundant human capital which still remains intact (Haq 1998, 31). 


\section{Rate of Return on Investment in Education}

Investment in education conceptually is the same as an investment on physical capital. It can be assessed by calculating the costs and benefits of education giving the rate of return to such investment. Rate of return is technically what equates the future stream of benefits with the present stream of costs. Social rate of return from education is defined as all the cost born by that society as a whole. It includes the fees, scholarships, administrative expenditures which are paid by the state or society (Cathal 1999). In social benefits, it is the level of education such as improved standards of hygiene, low rates of infant and child mortality, reduced rate of population growth, higher civic consciousness, greater political participation and an improved sense of national integration. For policy purposes, the social rate of returns is very important. The extract of various studies shows that:

- The primary education has the highest social rate of return, followed by secondary education.

- As national income increases, the return to all levels of education declines but primary education still has the highest rate of return.

- Technical education at all levels has generated considerable rate of return as far as sustainable development is concerned.

- South Asia and Sub-Saharan Africa shows the highest rate of return on investment.

\section{Economic Growth}

The several recent analysts place knowledge at the centre of growth process. Impressive statistics show that the economic growth in the West was based on the development of human capital which stimulated the growth of material resources, in turn the economic development of these nations (Todaro 1989).

Though East Asian miracle was based on many factors, all analysts agree on the central role that the primary education had played in shaping this miracle. It is clear from several studies that at all levels more educational opportunities helped to bring economic growth by (a) generating an extremely productive working force, (b) more opportunities of jobs for teachers, (c) creating a class of educated leaders to provide good governance and (d) promoting literacy and basic skills by providing relevant training and education. This type of education support modern trends within different groups in the society representing diverse attitudes (Todaro 1989). Table 6 shows the contributions of education in selected countries and regions. 
Table 6: Contribution of Education to Economic Growth

\begin{tabular}{|c|c|}
\hline Country & Growth Rate by Education \\
\hline Canada & 25.0 \\
\hline Ghana & 23.3 \\
\hline India & $27.0^{*}$ \\
\hline Argentina & 16.5 \\
\hline Nigeria & 16.0 \\
\hline United States & 15.0 \\
\hline Belgium & 14.0 \\
\hline Kenya & 12.4 \\
\hline Regions (1950-60s) & 17.2 \\
\hline Africa & 11.1 \\
\hline Asia & 8.6 \\
\hline Europe\& North America & 5.1 \\
\hline Latin America & \\
\hline
\end{tabular}

Source: World Bank 1993c \& * Loh 1995 for India.

The reason for the low contribution of education to economic growth in certain countries such as Nicaragua, Cuba and Sri Lanka etc., was that the complementary economic and social policies required to ensure sustainable human development were missing there. In fact sustainable economic growth can be achieved by providing adequately remunerated productive jobs to the educated people. It would act as an incentive to get education. Along with the creation of jobs opportunities, it is essential to ensure that educational performance is not hampered by poor health. For that purpose it is necessary that education must be a part of a wider human development strategy. Such complementary policies can reinforce educational progress. For instance, if a country with a 50 per cent literacy rate doubled its GDP, it could expect illiteracy to fall to 27.3 per cent (Anand and Ravallion 1993).

\section{Broader Social Impacts of Education}

Education is not the only source of better income and job opportunities for people. Although it ensures high economic growth rate but it has other valuable effects on social aspects. Education improves other social indicators of human development. It leads to better life expectancy and health care, more community participation and smaller family. It leads to high standards of living, more hygienic food and healthy leisure time activities.

\section{Key to Better Health Care}

Several empirical studies have confirmed a positive and very close relationship between improvements in health and education. Cross-country research has shown that a mother's schooling of one to three years is associated with a 20 per cent decline in the risk of childhood death. (World Bank 1997c). Another study reveals that if female participation at secondary level is doubled (as done in 1975, from 19 per cent to 38 per cent) it would check the infant mortality rate (IMR) to 31 from an alarming figure of 85 (reduced by 64 per cent). The results were much more than those attained by most 
discussed routes, for instance, doubling the number of doctors would have reduced the IMR by 5 per cent and doubling per capita income by reduced 6 per cent (Subarao and Raney 1995). If both parents are literate, it can reduce the infant mortality rate by 27 per thousand (Schultz 1998).

Education, particularly of females, greatly improves the ability to manage basic child care, increases nutrition value of diet, ensures more effective diagnosis of diseases and improves elementary hygienic conditions. There is a close correlation between paternal education and infant mortality. Both are inversely proportional to each other. Historical evidence indicates that there is a dramatically sharp decline in child labour as the primary education becomes universal.

\section{Most Effective in Controlling Population Explosion}

Role of education in bringing down the rate of population growth is even more dramatic. It has been observed that more education reduces the population growth rate in the society. One reason may be that more education leads to higher income group and larger families are not in fashion in that group. The other obvious reason is the liberalisation of society and more women empowerment to take decision about their family size. More education also facilitates more mobility, access and knowledge of services provided for keeping family size in control. All these measures results in significant reduction in growth of family size and control over the threat of population explosion which is a potent threat to already scares resources of South Asia.

In the most populous country of the region, Bangladesh, 66 per cent among women with more than secondary education used contraceptive as compared to 47 per cent among women with secondary education, while 35 per cent among those with primary education used contraceptive as compared to 27 per cent women with no education (World Bank 1993a).

The acquisition of knowledge delays the age of marriage. One reason is that to acquire higher education is a matter of time also and other is that it exhibit greater selfconfidence on the part of educated women who have better job opportunities. Education also empowers women to protect their reproductive rights and to convince their husbands to have a smaller family size. Since education reduces the rate of population growth and a lower fertility rate in the society, it further helps to minimise the burden of extra new students on existing educational system. With a slow growing school-age population, state can increase spending to provide more years of schooling or better quality of education.

\section{Poverty Reduction}

Education plays an effective role in poverty reduction. Many studies concluded that a rise in literacy rate is reciprocated by a recordable decline in poverty level (Fields 1980, Tilak 1989). Indeed the economic growth record of South Asia has been satisfactory. Despite high population growth, an average 5 per cent growth rate per annum in GNP and 3 per cent per annum in per capita income was observed. Still South Asia is the home of 500 million poorest people. The greatest policy failure is that the increasing prosperity is not reflected in the lives of ordinary people. The pace of economic growth is unevenly distributed among different regions in South Asia. Pakistan shows the highest rate of increase (163 per cent) between 1970-93 in real per capita GDP in \$PPP, while Sri Lanka experienced the lowest increase (71 per cent). The real issue is not the quantum of 
growth but its quality and distribution (Haq 1999). A comparison of South Asian poverty profile with other regions of the World is shown in the Table 7.

Table 7: Comparison of Poverty Profile of South Asia with other Regions.

\begin{tabular}{|c|c|c|}
\hline Regions & $\begin{array}{c}\text { People in } \\
\text { Poverty*1993(millions) }\end{array}$ & $\begin{array}{c}\text { \%age Share in Global } \\
\text { Poverty }\end{array}$ \\
\hline South Asia & 515 & 40 \\
\hline Sub Saharan Africa & 219 & 17 \\
\hline East Asia (excel. China) & 94 & 7 \\
\hline China & 352 & 27 \\
\hline L. America \& Caribbean & 110 & 8 \\
\hline Arab States & 11 & 1 \\
\hline Developing world & 1,301 & 100 \\
\hline
\end{tabular}

*Defined as \$1 day per person based on 1985 PPP \$ Source: UNDP 1997a.

According to the latest World Bank estimates 53 per cent of population in India, 12\% in Pakistan 29.5 in Bangladesh, 45 in Sri Lanka and 53 per cent in Nepal are subsisting in absolute poverty. The number of poor in Pakistan is well over 40 million. Education contributes enormously in poverty reduction in rural areas. A study in the Republic of Korea, Nepal, Malaysia and Thailand suggests that education greatly raises the productivity of small farmers and in this way, reduces absolute poverty (Saeed 2000).

\section{Reducing Inequality}

There are two views about the role of education in reducing inequality. On one hand education is viewed as a great equalizer. It allows everyone better access to economic, social and political opportunities. Especially in egalitarian societies of third world universal education promotes a sense of social equality. At the same time, it is true that an important component in income inequality may be the inequality of educational opportunities. A recent study concludes that over one half of income inequality in the United States of America can be attributed to such inequality (Haq 1998)

Keeping in view the arguments of both view points, it can be stated that if the entire population is educated (as in East Asia and other developed countries) education would exercise the equalizing influence on income distribution. If only a small fraction of population is educated (as in the case of South Asia), the dual standards are likely to prevail and income inequalities may become more pronounced. (Tilak 1998) concludes that as the labour force becomes more educated; income is redistributed from top 20 per cent to bottom 80 per cent or population.

In South Asian countries the existence of more than one education systems, one for elite class and the other for ordinary people, ultimately widens the gap both in social and economic aspects.

\section{Good Governance}

Education is a basic component of social cohesion and national identity. People, having civic sense, awareness of their rights and duties and habitual obedience to state 
laws, prove to be an asset in the formation of a political society. They also generate good governance from state institutions.

Education also plays a key role in the democratization process, as demonstrated by the experience of nineteenth century America and Europe. Education enables people to resist dictatorship and people organise politically thus ensuring social justice and democracy. No educated society can be politically, socially and economically repressed for too long.

Education levels also have impacts on public opinion formulation. As the example of Indian state of Kerala, shows that 90 per cent literacy rate in Kerala as compared to 52 per cent in India as a whole, resulted in the newspaper reading of half of literate population compared to 20 per cent in other parts of India (Ramachandrau 1998). Thus education can improve the depth and quality of public opinion.

Education provides the basis for the better democratic citizenship. As voters are the basis of the democratic system, their awareness generates high standards of public representation in the elected governmental institutions. They also provide effective accountability of public officers, not to become tyrannical to the masses. In South Asia, where democracies are transitional, only education can provide stability to democratic process.

\section{Conclusion}

South Asia-the region, proud of its culture heritage and magnificent past, had been the centre of the great civilizations and religions. But at the same time it has become the poorest and the most malnourished region. It has also emerged as the most illiterate region having lowest gender sensitivity level. It is the home of 395 million illiterate adults (nearly half of the world's total) and over 50 million out of school children (2/5 of the world's total). Despite its satisfactory economic performance, what it lacks is the sufficient human resources development which can serve as a basis for sustainable economic development. On the other hand, it can be developed as 'the most dynamic region' in the twenty-first century if the human development is taken as a priority by their respective governments. It needs generous investment in developing human capital as a part of comprehensive development strategy. Nonetheless the basic education for all is the critical components of any such strategy but the technical education to produced skilled man power should be a priority. What is lacking! Not the financial resources, but the political commitment. Political commitment and society's full participation can meet the already formidable educational challenges of South Asia. 蹸

\section{References}

Spot Light on Regional Affairs (2000). XIX(8 \& 9).

Anand, S., \& Ravallion, M. (1993). Human Development in Poor Countries: On the role of Private Incomes \& Public Services. Journal of Economic Perspective, 1(7), 133-150.

Beckers, G. S., Murphy, K. M., \& Tamura, R. (1993). Human Capital. Chicago: The University of Chicago Press.

Cochrane, S. (1979). Fertility and Education: What Do We Really Know? Baltimore: Johns Hopkins University Press. 
Druze, J., \& Amrita, S. (1995). India: Economic Development and Social Opportunity. New Delhi: Oxford University Press.

Engels, F. (1845). Speeches in Elberfeld in K. Marx and F Engels: Collected Works (Vol. 4). Mosin: Progress Publisher.

Fields, G. (1980). Education and Income Distribution in Developing Countries: A Review of Literature (No. World Bank Staff Working Paper No. 402). Washington D. C.: World Bank.

Foster, A. D., \& Rosenzweing, M. R. (1995). Learning by Doing and Learning from Others: Human Capital \& Technological Change in Agriculture. Journal of Political Economy, 6(103), 1176-1209.

Haq, M. (1997). Human Development in South Asia. Karachi: Oxford University Press.

Haq, M. and Haq, Khadija. (1998). Human Development in South Asia. Karachi: Oxford University Press.

Haq, M. (1999). Human Development in South Asia: The Crisis of Governance. Karachi: Oxford University Press.

Jamison, D., \& Lau, L. (1982). Farmer Education and Farm Efficiency. Baltimore: Johns Hopkins University Press.

Loh, J. (1995). Education and Economic Growth in India: An aggregate production function approach. In NCERT (Ed.), School effectiveness and learning achievement at primary stage. New Delhi.

Marshal, A. (1980). Principles of Economics. London: Macmillan.

O’Donoghue, C. (1999). Estimating the Rate of Return to Education using Microsimulation. The Economic and Social Review, 30(3), 249-265.

Okemakinde, T., \& Olaniyan, D. A. (2008). Human Capital Theory: Implications for Educational Development. European Journal of Scientific Research, 24(2), 157-162.

Ramachandra, V. K. (1998). On Kerala Development Achievement. In Dreze \& Sen (Eds.), Indian Development: Selected Regional Perspective. New Delhi: Oxford University Press.

Rosegrant, M. W., \& Evensong., R. (1993). Agricultural Productivity Growth in Pakistan \& India: A comparative Analysis. Islamabad: Pakistan Institute of Development Economics.

Rosenweig, M. R. (1995). Why Are There Returns in Schooling? American Economic Review 85(2), 153-158.

Saeed, A. (2000). Poverty in South Asia: Predicament \& Prospects. Journal of Regional Studies, XVIII(4).

Schultz, T. P. (1998). Education, Investment and Return. In H. B. Chenery \& Srinivasan (Eds.), Handbook of Development Economics (Vol. 1 \& 2). Amsterdam: North Holland. 
Smith, A. (1776). The Wealth of Nations. London.

Subaro, K., \& Raney, L. (1995). Social Gain from Female Education: a cross national study. Economic Development and Cultural Change, 44, 105-120.

Tilak, J. B. G. (1998). Economics of Vocationalisation: A review of evidence. Canadian and International Education, 17(1).

Tilak, J. B. G. (1998 ). Education and its Relations to Economic Growth, Poverty and Income Distribution: Past Evidence and Future Analysis. Washington, D.C.: World Bank.

Tilak, J. B. G. (2002). Building Human Capital in East Asia: What Others Can Learn. Retrieved from http://siteresources.worldbank.org/WBI/Resources/wbi37166.pdf

Todaro, P. M. (1989). Economic Development in the Third World. New York Longman.

UNDP (1997). Human Development Report 1997. New York: Oxford University Press.

UNICEF (1997 ). State of the World's Children 1997 Oxford: Oxford University Press.

World Bank (1993a). Annual Report 1993. Washington, D. C. : World Bank.

World Bank (1993b). Appraisal Report on Female Secondary School Assistance: World Bank.

World Bank (1993c). The East Asian Miracle Economic Growth and Public policy. New York: Oxford University press.

World Bank (1995a). Annual Report 1995. Washington, D.C: World Bank.

World Bank (1995b). Monitoring Environmental Progress. Washington, D.C: World Bank.

World Bank (1997). Primary Education in India. Washington, D.C: World Bank.

"You are not here merely to make a living. You are here to enable the world to live more amply, with greater vision, and with a finer spirit of hope and achievement. You are here to enrich the world. You imperish yourself if you forget this errand.”

- Woodrow Wilson 